\title{
MOLECULAR CHARACTERIZATION OF COPY'S FROG HYDROPHYLAX LEPTOGLOSSA BASED ON 16S RRNA GENE
}

\author{
Mehrab Chowdhury ${ }^{1}$, Abu Sinha ${ }^{1}$, Md. Salim Mahabub Rony ${ }^{1}$, Hawa Jahan ${ }^{3}$ \\ Ashfaqul Muid Khandaker ${ }^{2}$ and Rowshan Ara Begum ${ }^{* 2}$ \\ Department of Zoology, Jagannath University, Dhaka-1100, Bangladesh
}

\begin{abstract}
Copy's frog, commonly observed in Bangladesh, is ecologically important for evergreen forest. Sample was collected from Satchari National park, Hobigonj, Sylhet. Attempts were made to combine morphological and molecular techniques for identification and analysis of evolutionary relation of Copy's frog with anuran species. Morphological identification of Hydrophylax sp. was conducted based on distinguishing characteristics of the body and different body measurement parameter. The species was identified morphologically as Hydrophylax leptoglossa based on the taxonomic key of finger toes and formula was $3>1>4>2$. Simultaneously genomic DNA was isolated using CTAB extraction method. The 16S rRNA gene was amplified from the genomic DNA by polymerase chain reaction method using the pair of universal primers. Amplified product was a $308 \mathrm{bp}$ fragment that generated AT/GC ratio of $1.08 \%$ once sequenced. In the present study comparative analysis of intraspecific and interspecific variation was conducted based on nucleotide sequence of 16S rRNA gene collected from GenBank. The intraspecific variation compares between Southeast Asia and Bangladesh was $1.29 \%$ for $16 \mathrm{~S}$ rRNA gene. The interspecific genetic divergence was studied between $H$. leptoglossa and $H$. tytleri was observed $14.29 \%$. The nucleotide sequence of the present study will be used as DNA barcode for that particular individual collected from Sylhet, Bangladesh. Furthermore, a molecular phylogenetic tree was constructed, where all the anuran species from a monophyletic group. Four species of Hydrophylax form monophyletic group and is consistent with relation based on morphology.
\end{abstract}

Key words: 16S rRNA gene, Polymorphic loci, Hydophylax leptoglossa

\section{INTRODUCTION}

International Union for Conservation of Nature has categorized the amphibians as an endangered group of animals (IUCN 2015, Berger et al., 1998). The number of amphibian species is still increasing and there is

*Author for Correspondence: <rowshanbegum@du.ac.bd>, ${ }^{2}$ Genetics and Molecular Biology Laboratory, Department of Zoology, University of Dhaka, ${ }^{3}$ Division of Evolution and Genomic Sciences, School of Biological Science, Faculty of Biology, Medicine and Health, University of Manchester, UK

@2021 Zoological Society of Bangladesh DOI: https://doi.org/10.3329/bjz.v49i1.53686 
least a third of known amphibian species (Bickford et al., 2007, Fouquet et al., 2007). While some amphibian species are disappearing every year, a number of new species are being discovered (Welsh et al., 1998). They have different life stages, high phenotypic plasticity and high level of cryptic diversity between species. These traits often make it most difficult to correctly identify species, especially at early life-stages (Larson et al., 1993). Moreover, most amphibian have complex life cycles which make the identification complicated (Bickford et al., 2007). Hence, recently they have been in the center of research and public attention.

Morphometrics, refers to the quantitative analysis of form, a concept that encompasses size and shape is commonly used for morphological identification. Morphometric analyses are commonly performed on organisms, and are useful in analyzing their fossil record, the impact of mutations on shape, developmental changes in form, covariances between ecological factors and shape, as well for estimating quantitative-genetic parameters of shape (Hasan et al., 2014).

Nowadays species identification by using conventional keys only is not enough. Molecular techniques should be implemented for correct identification. In that case, mitochondrial DNA (mtDNA) plays an important role to species identification and evolutionary relation study. Among mtDNA genes 16S ribosomal RNA (16S rRNA) gene is a special region of mitochondrial genome and has been considered as one of the most informative regions used in phylogenetic studies (Bej et al., 2012; Patwardhan et al., 2004). It is a component of the 30S small subunit of prokaryotic ribosome and is $1.5 \mathrm{~kb}$ in length (Devereux and Wilkinson 2004). 16S rRNA gene variation between species and within species is stable (Yang et al., 2014). Although it was originally used to identify an organism, 16S rRNA sequencing was subsequently found to be capable of reclassifying the organism into completely new species, or even genera and is also used for bar coding of certain amphibians (Vences et al., 2005; Weisburg et al., 1991).

To investigate the genetic characteristics of $H$. leptoglossa in this study a partial sequence of the 16S rRNA of $H$. leptoglossa was determined. The sequence was aligned with other sequence of $H$. leptoglossa and $H$. tytleri to study the number of polymorphic sites. Phylogenetic relationship was observed by construct a phylogenetic tree.

\section{MATERIAL AND METHODS}

Morphological analysis: The Cope's frog or locally known as long-tongued frog, Hydrophylax leptoglossa was collected from Satchari National Park, Hobigonj, Sylhet. The fresh specimen was brought to the laboratory of Genetics 
and Molecular Biology, Department of Zoology, University of Dhaka for further study. The sample was morphologically identified by conventional method. The measurement of different body part of collected frog is shown in Fig. 1. The sample was stored in refrigerator, minimum temperature at $4^{\circ} \mathrm{C}$ as voucher sample, labeled as $\mathrm{H} 1$.

DNA extraction, PCR amplification and sequencing: Genomic DNA was extracted from $0.05 \mathrm{gm}$ muscle tissue of the observed frog species following a method

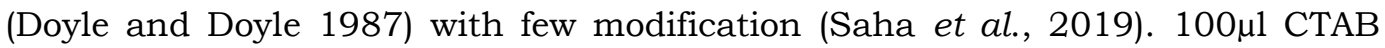
(Cetyltrimethyl ammonium bromide) extraction buffer and $10 \mu 1$ of proteinase $\mathrm{k}$ were added. This mixture was incubated at $56^{\circ} \mathrm{C}$ for overnight. After digestion, equal volume of phenol chloroform was added with the supernatant and centrifuged at $13000 \mathrm{rpm}$ for $5 \mathrm{~min}$. DNA was precipitated with ethanol and dissolved in distilled water. Partial region of $16 \mathrm{~S}$ rRNA gene was amplified using universal primers and was visualized in 1.5\% agarose gel (Faucher et al., 2016). Then, the amplified PCR product was purified using a purification kit (Saha et al., 2019). Finally, nucleotide sequence was determined using direct sequencing method.

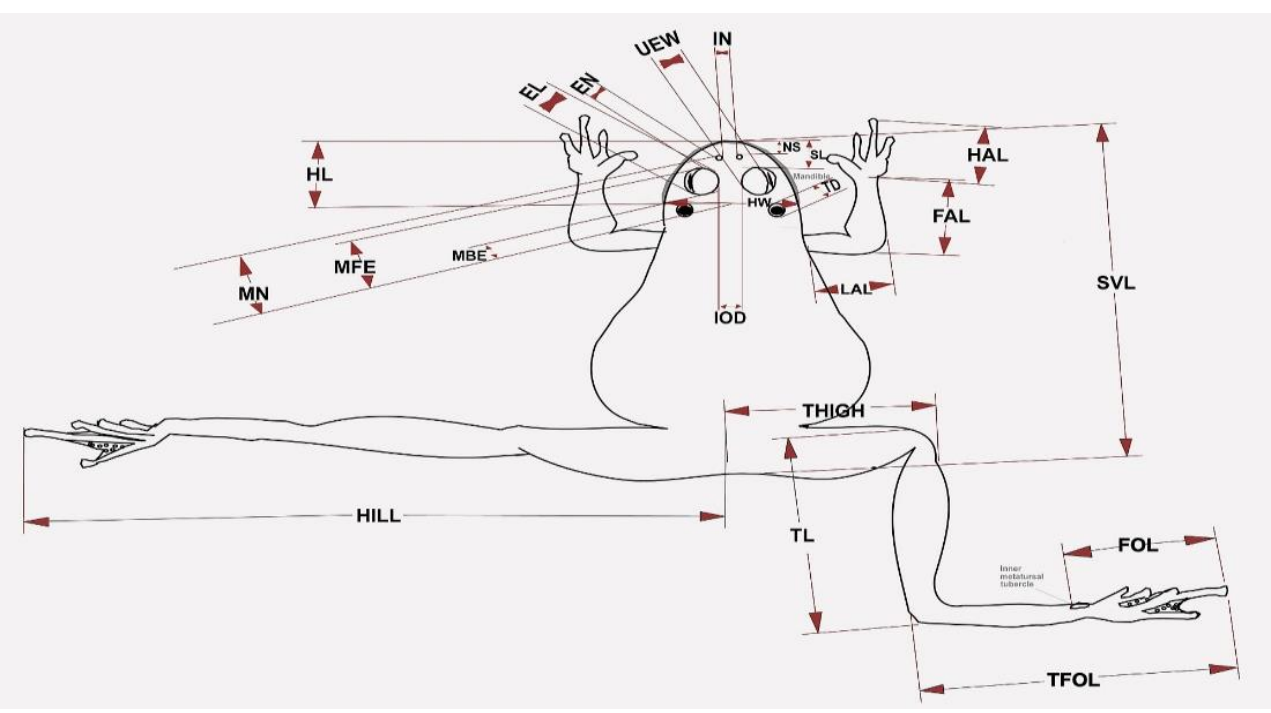

Fig. 1: Measurement of different part of Cope's frog.

Bioinformatics analysis: 16S rRNA gene sequence of experimental frog species and other existing sequence of Cope's frog were collected from GenBank database (NCBI). Alignment was done with the help of serial cloner software. MEGA 7 software was also used for multiple sequence alignment which was 
followed by polymorphic site analyses. Phylogenetic tree was constructed using neighbor joining method (Saha et al., 2019).

\section{RESULTS AND DISCUSSION}

Morphological analysis: The dorsal part of the copy's frog $H$. leptoglossa was dark brown with scattered black spots (Figure-2, Table-1). Head and back skin is distinctly granulated. Tympanum is distinct and about three-fourth of the eye diameter. Fingers are free and toes are two-third webbed. Tips of all digits are slightly dilated. The length of fingers was compared and $3^{\text {rd }}$ one was found to be largest and $2^{\text {nd }}$ one was smallest. The rest two are as follows and formula was $3>1>4>2$ (Table-2). Tibio-tarsal articulation reaches beyond the snout. Collected sample was under the Class Amphibia, Order Anura. That species is under family Ranidae. The genus was Hylarana and species was leptoglossa (Hasan et al., 2014)

Collected sample was morphologically similar to that of $H$. leptoglossa. It was initially identified by body color, special mark and other measurement as describe by Hasan et al., 2014. Present study found the SVL length of $H$. leptoglossa was $51.816 \mathrm{~mm}$ and similar length was observed by Hasan et al., 2014 mentioned the SVL length of $H$. leptoglossa was between $45-70 \mathrm{~mm}$. They also mentioned that head was granulated and tymphanum was distinct which was similar to my data. They mentioned relative finger length was $3>1>4>2$ and was fully matched with present investigation. So, it was clear that the species was $H$. leptoglossa according to Hasan et al., 2014. Recently Hylarana leptoglossa is renamed Hydophylax leptoglossa

(https: / /www.uniprot.org/taxonomy/1659774).

Table-1. Morphometric characteristics of $\mathrm{H}$. leptoglossa

\begin{tabular}{ll}
\hline \multicolumn{1}{c}{ Objective } & \multicolumn{1}{c}{ Charateristics } \\
\hline Body size & Medium \\
Dorsal color & Dark brown \\
Ventral color & Gray with white spot \\
Head & Granulated \\
Tympanum & Distinct \\
Teeth & Vomerine \\
Web (finger) & Present and free \\
Web (toe) & Two third webbed \\
\hline
\end{tabular}

DNA extraction: DNA extraction of the samples used in the present study was performed successfully. Band of the extracted genomic DNA was visualized under the ultraviolet transilluminator and shown in Figure 3. 
Table-2. Morphometric measurement of different body parts (parameters) of observed in $\boldsymbol{H}$. leptoglossa

\begin{tabular}{|c|c|c|c|}
\hline \multicolumn{2}{|c|}{$\begin{array}{c}\text { Body } \\
\text { measurement (mm) } \\
\text { Criteria Size }\end{array}$} & \multicolumn{2}{|c|}{$\begin{array}{c}\text { Toe length } \\
\text { Criteria Size }\end{array}$} \\
\hline${ }^{*} \mathrm{SVL}$ & 51.816 & $\mathrm{~F} 1$ & 7.493 \\
\hline EN & 3.606 & $\mathrm{~F} 2$ & 5.359 \\
\hline $\mathrm{HL}$ & 14.222 & F3 & 7.950 \\
\hline EL & 2.59 & F4 & 6.629 \\
\hline $\begin{array}{l}\text { HW } \\
\text { UEW }\end{array}$ & $\begin{array}{l}13.766 \\
4.648\end{array}$ & & \\
\hline MN & 12.87 & & \\
\hline TD & 3.454 & & \\
\hline SL & 7.772 & & \\
\hline HAL & 11.637 & & \\
\hline MFE & 9.982 & & \\
\hline FAL & 8.02 & & \\
\hline MBE & 4.013 & & \\
\hline THIGH & 20.75 & & \\
\hline IN & 4.318 & & \\
\hline TL & 23.59 & & \\
\hline IOD & 5.538 & & \\
\hline TFOL & 30.60 & & \\
\hline
\end{tabular}

\{*Abbreviations are explained as follows: SVL (snout-vent length), HL (head length), HW (head width), MN (distance from back of mandible to nostril), SL (snout length), MFE (distance from back of mandible to front of eye), MBE (distance from back of mandible to back of the eye), IN (internarial distance), IOD (interorbital distance), EN (distance from front of eyes to nostril), NS (nostril-snout length), EL (eye length), UEW (maximum width of upper eyelid), TD (tympanum diameter), TEL (tympanum-eye length), HAL (hand length), FAL (forearm length), THIGHL (thigh length), TL (tibia length), TFOL (length of tarsus and foot), FOL (foot length), and IMTL (inner metatarsal tubercle length).\}

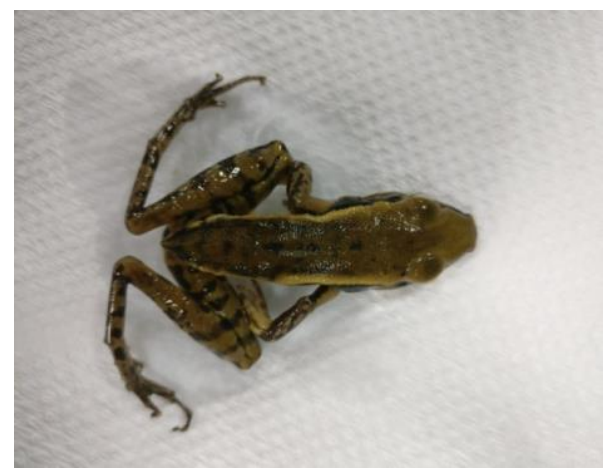

Fig.2. Dorsal view of Cope's frog observed in present study. 


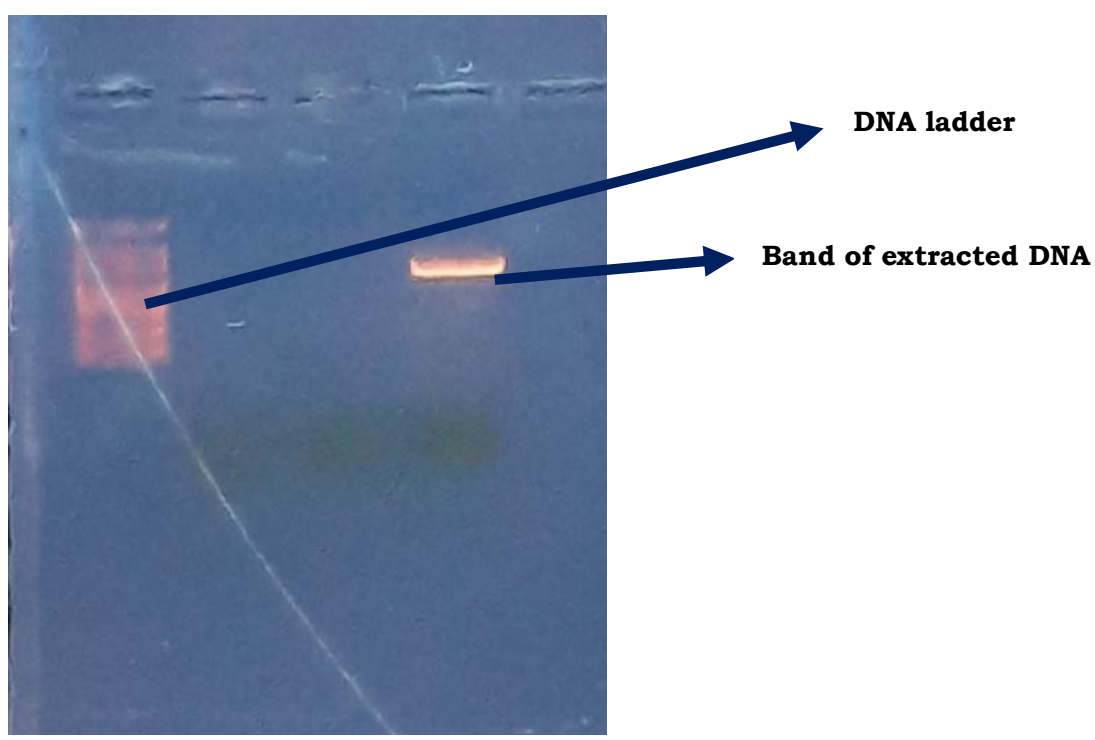

Fig. 3. Extracted genomic DNA band of $H$. leptoglossa showing in $1.0 \%$ agarose gel.

Amplification of $16 \mathrm{~S}$ rRNA gene by polymerase chain reaction: Extracted genomic DNA of observed species was prepared for polymerase chain reaction. The amplified PCR product was then visualized by running them through agarose gel of concentration $1.5 \%$ and shown in Figure 4. Compared with DNA marker, it was revealed that amplified gene was around 600 base pair long.

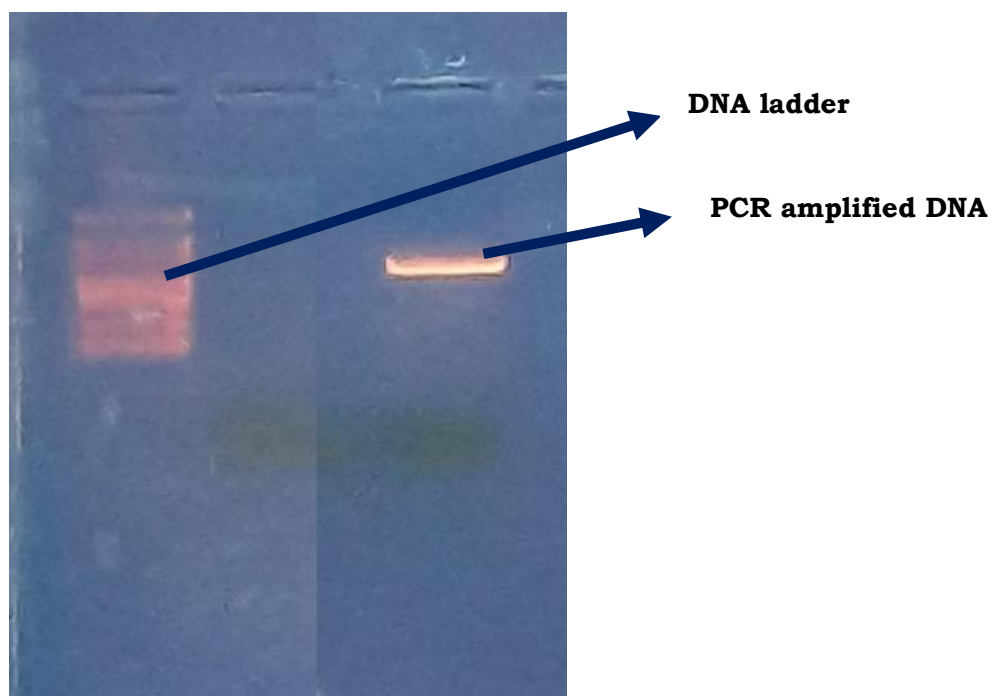

Fig.4. Amplified DNA band of 16S rRNA gene of $H$. leptoglossa showing in $1.5 \%$ Agarose gel 
Nucleotide sequences of $16 \mathrm{~S}$ rRNA gene: Nucleotide sequence was obtained by direct sequencing method and $308 \mathrm{bp}$ of nucleotide sequence was determined. The obtained sequence was submitted to the GenBank database and the accession number is MN477195. Of the nucleotide sequences four nitrogen bases were analyzed and percentages are shown in table 3.

Table 3. Percentages of nucleotide base pair of observed anuran species $\boldsymbol{H}$. leptoglossa

\begin{tabular}{ll}
\hline Nucleotide base name & Percentage\% \\
\hline Adenine $(\mathrm{A})$ & 28.57 \\
Cytosine $(\mathrm{C})$ & 24.35 \\
Guanine $(\mathrm{G})$ & 23.70 \\
Thymine (T) & 23.38 \\
G-C content & 8.05 \\
A-T content & 51.95 \\
AT/GC ratio & 1.08 \\
\hline
\end{tabular}

Within the determined sequence the content of adenine, cytosine, thymine and guanine were $88,75,73$ and 72 , respectively. The AT/GC ratio was $1.08 \%$ as shown in table 3 and is matches with that of $H$. leptoglossa found in GenBank database with the accession number AB530528.

Intraspecific variation of 16S rRNA gene: Multiple sequence alignment was done to investigate the intraspecific comparison of the 16S rRNA gene among three individuals of $H$. leptoglossa. The sequence that was determined in the present study was compared with the sequences of other two individuals retrieved from the GenBank database of National Center for Biotechnology Information (NCBI). The sequences obtained from NCBI were done on individuals collected from Bandarban, Bangladesh (accession number AB530528) and Southeast Asia (accession number AB530526). Four polymorphic sites were revealed after comparing the intraspecies sequences among $H$. leptoglossa (Present study, Sylhet), $H$. leptoglossa (Bandarban, Bangladesh) and $H$. leptoglossa (Southeast Asia) and are shown in table 4. All of the sequences were

Table 4. Polymorphic sites analysis of 16S rRNA gene of $H$. leptoglossa from Bangladesh, Southeast Asia and present study

\begin{tabular}{lllll}
\hline Serial & Polymorphic site & *HS & HB & HSA \\
\hline 01 & 213 & A & T & - \\
02 & 214 & G & G & - \\
03 & 215 & C & C & - \\
04 & 307 & T & T & C \\
\hline
\end{tabular}

"Sequence labeled "HS" stands for H. leptoglossa from present study (Sylhet), HB stands for $H$. leptoglossa from Bandarban, Bangladesh and "HSA" stands for South-east Asia. 
Table 5. Polymorphic sites analysis of nucleotide sequences of $16 \mathrm{~S}$ rRA gene between $H$. tytleri, and $\boldsymbol{H}$. leptoglossa (present study)

\begin{tabular}{|c|c|c|c|}
\hline Serial No & Polymorphic sites & HT & HL \\
\hline 1 & 15 & $\mathrm{C}$ & $\mathrm{G}$ \\
\hline 2 & 18 & $\mathrm{~T}$ & $\mathrm{C}$ \\
\hline 3 & 32 & $\mathrm{C}$ & $\mathrm{T}$ \\
\hline 4 & 36 & A & G \\
\hline 5 & 106 & $\mathrm{~T}$ & $\mathrm{C}$ \\
\hline 6 & 122 & $\mathrm{~T}$ & $\mathrm{C}$ \\
\hline 7 & 163 & A & $\mathrm{T}$ \\
\hline 8 & 164 & A & $\mathrm{T}$ \\
\hline 9 & 165 & C & A \\
\hline 10 & 203 & $\mathrm{~T}$ & A \\
\hline 11 & 207 & C & $\mathrm{T}$ \\
\hline 12 & 211 & $\mathrm{C}$ & $\mathrm{T}$ \\
\hline 13 & 212 & $\mathrm{C}$ & $\mathrm{T}$ \\
\hline 14 & 214 & G & A \\
\hline 15 & 215 & C & - \\
\hline 16 & 217 & $\mathrm{C}$ & $\mathrm{T}$ \\
\hline 17 & 218 & $\mathrm{C}$ & $\mathrm{T}$ \\
\hline 18 & 219 & $\mathrm{~T}$ & G \\
\hline 19 & 220 & $\mathrm{~T}$ & A \\
\hline 20 & 221 & $\mathrm{~T}$ & A \\
\hline 21 & 224 & A & $\mathrm{T}$ \\
\hline 22 & 227 & A & $\mathrm{T}$ \\
\hline 23 & 230 & $\mathrm{C}$ & $\mathrm{T}$ \\
\hline 24 & 233 & A & $\mathrm{T}$ \\
\hline 25 & 234 & C & $\mathrm{T}$ \\
\hline 26 & 235 & A & $\mathrm{T}$ \\
\hline 27 & 236 & $\mathrm{~T}$ & C \\
\hline 28 & 239 & $\mathrm{G}$ & A \\
\hline 29 & 242 & A & $\mathrm{C}$ \\
\hline 30 & 244 & C & $\mathrm{T}$ \\
\hline 31 & 245 & $\mathrm{~T}$ & - \\
\hline 32 & 246 & G & - \\
\hline 33 & 250 & A & $\mathrm{T}$ \\
\hline 34 & 259 & A & $\mathrm{T}$ \\
\hline 35 & 273 & A & G \\
\hline 36 & 284 & $\mathrm{~T}$ & $\mathrm{C}$ \\
\hline 37 & 285 & A & $\mathrm{T}$ \\
\hline 38 & 286 & $\mathrm{~T}$ & A \\
\hline 39 & 294 & $\mathrm{~A}$ & $\mathrm{G}$ \\
\hline 40 & 295 & $\mathrm{~T}$ & $\mathrm{C}$ \\
\hline 41 & 296 & $\mathrm{G}$ & A \\
\hline 42 & 299 & A & $\mathrm{T}$ \\
\hline 43 & 302 & A & $\mathrm{T}$ \\
\hline 44 & 308 & C & $\mathrm{C}$ \\
\hline
\end{tabular}

Sequence labeled "HT" Stands for H. tytleri and "HL" stand for H. leptoglossa.

found to be approximately $308 \mathrm{bp}$ in length. The intraspecific genetic diversion was $1.29 \%$ where the species were compared with different countries.

Interspecific variations of sequences: Inter specific sequences of $16 \mathrm{~S}$ rRNA gene of $H$. leptoglossa and $H$. tytleri were compared. All the sequences were found to be approximately $308 \mathrm{bp}$ in length. 44 polymorphic sites were observed (Table 5). Inter species variation among these species was $14.29 \%$. 


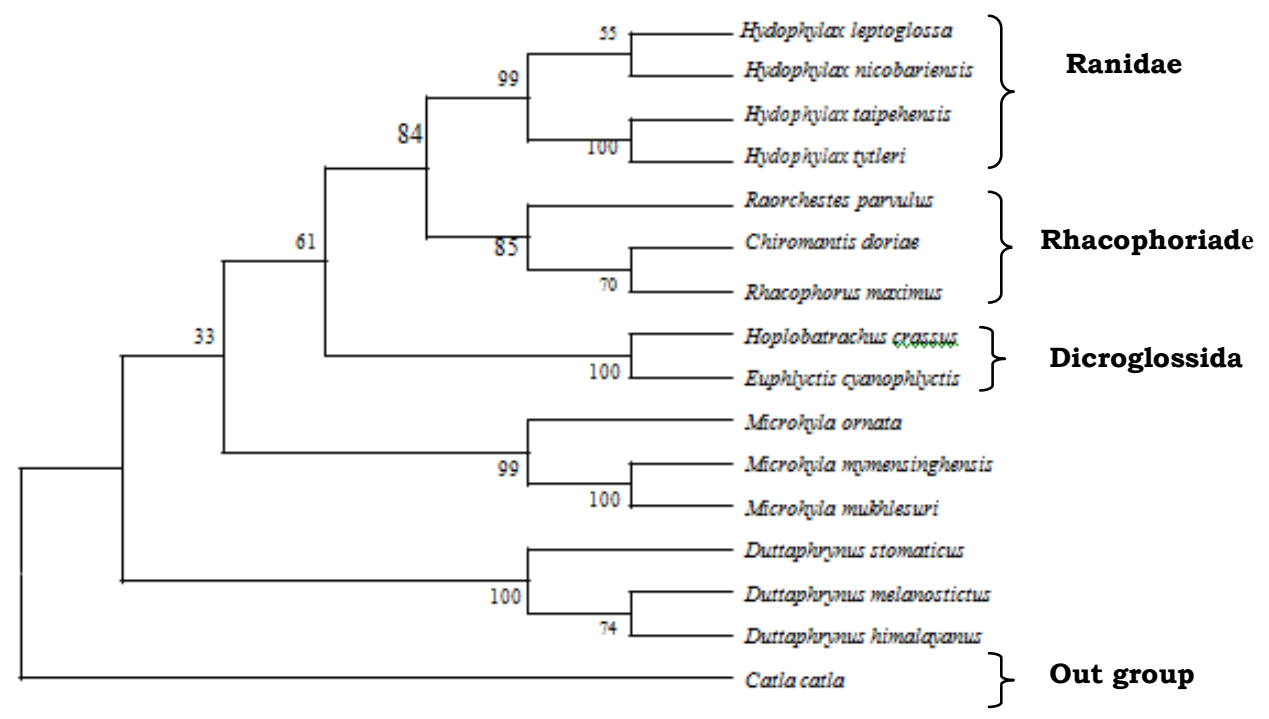

Fig.5. Molecular phylogenetic tree for Cope's frog according to the neighbor joining method based on the partial nucleotide sequences for the 16S rRNA gene where Catla catla used as outgroup.

Phylogenetic analysis: To identify the phylogenetic position of $H$. leptoglossa of the present study a phylogenetic tree was constructed. As Cope's frog was an anuran species, a comparative study was performed among anuran from Ranidae, Rhacophoridae, Dicroglossidae, Microhylidae and Bufonidae family using the neighbor joining method, where Catla catla was used as an out group based on 16S rRNA. In the present study, four species of Hydophylax namely $H$. leptoglossa, $H$. nicoberebsis, $H$. taipenensis and $H$. tytleri, belong to same family Ranidae, form a monophyletic clade with bootstrap value 99 (Figure-5). Similar monophyletic clade was observed by Hasan (2012). Among 15 Anuran species $H$. leptoglossa and $H$. tapiensis formed a monophyletic group with bootstrap value was 99. Furthermore, Rhacophorus parvulus, Chiromantis doriae and Rhachophorus maximus belong to Rhacophoriade family form a monophyletic clade which bootstrap value was 84 and this relationship was not acceptable. So far, the species belong to family Ranidae was closely related to those of the family Rhacophoridae. So, the phylogenetic relationship of present study was similar to that of Hasan (2012) study and the phylogeny based on morphology.

\section{CONCLUSION}

Partial nucleotide sequence of 16S rRNA gene of copy's frog Hydrophylax leptoglossa was determined and will be used as DNA barcode for that particular 
individual collected from Sylhet, Bangladesh. The sequence was initially used to analyze a molecular phylogenetic tree. To confirm the present observation of the molecular taxonomic position of the present anuran species, further study is required based on nucleotide sequences of $12 \mathrm{~S}$ rRNA, COI, cytochrome $b$, ND4 and ND1 genes from the mitochondrial genome.

Acknowlesdgement: The present study was funded by National Science and Technology Fellowship from Science and Technology ministry of Bangladesh.

\section{LITERATURE CITED}

BERGER, L., SPEARE, R., DASZAKD, P., GREenE, D. E., CUnNinghamF, A. A., GOGGing, C. L., SOLOCOMBEH, R., RAGANI, M. A., HAYTT, A. D., MCDONALDJ, K. R., HINESK, H. B., LIPS, K. R., MARANTELLIM, G. and PARKES, H. 1998. Chytridomycosis causes amphibian mortality associated with population decline in the rainforests of Australia and central America. Pro. of the Na. Aca. of Sci. of the U. S. of America. 95(15): 9031-9036.

BICKFORD, D., LOHMAN, D. J., SODHI, N. S., MEIER, R., WINKER, K., INGRAM, K. K. and DAS, I. 2007. Cryptic species as a window on diversity and conservation. Trends in Eco. and Evo. 22: 148-155.

BEJ, D., SAHOO, L., DAS, S. P., SWAIN, S., JAYASANKER, P., DAS, P. C., ROUTRAY, P., SWAIN, S. K., JENA, J. K. and DAS, P. 2012. Complete mitochondrial genome of Labeo rohita. MitochondrialDNA. 23(6): 441-443.

DEVEREUX, R and WILKINSON, S. S. 2004. Isolation of plant DNA from fresh tissue. Focus. 12: 1315.

DOYLE, J. and DOYLE, J. L. 1987. Genomic plant DNA preparation from fresh tissue CTAB method. Phytochem Bull. 19(11): 11-15.

FOUQuet, A., GILles, A., Vences, M., MARTY, C., BlANC, M. and GEMMELl, J. 2007. Underestimation of species richness in neotropical frogs revealed by mtDNA analyses. PLOS One. 2(10): 1109-1112.

FAUCHER, L., GOODE, C. and AMAUD, J. F. 2016. Development of nuclear microsatellite loci and mitochondrial single nucleotide polymorphism of the natterjack toad bufo (Epidalea) calmita (Bufonidae), use next generation sequencing and competitive allele specific PCR (KASPar). Journal of heredity. 107: 660-665.

HASAN, M. K., KHAN, M. H. and FEEROZ, M. M. 2014. A Photographic Guide to Wildlife of Bangladesh. Arannayk Foundation, Dhaka, Bangladesh. 400-500pp.

HASAN, M., ISLAM, M. M., KHAN, M. M. R., ALAM, M. S., KURABAYASHI, A., IGAWA, T., KURAMOTO, M. and SUMIDA, M. 2012.Cryptic Anuran Biodiversity in Bangladesh Revealed by Mitochondrial 16S rRNA Gene Sequences. Zool. Sci. 29: 162-172. 
IUCN. 2015. Red list of BD. Vol: 4, Reptilia and Amphibia.

LARSON, A. and CHIPPINDALE, P. 1993. Molecular approaches to the evolutionary biology of plethodontid salamanders. Herpetologica. 49(2): 204-215.

PATWARDHAN, A., RAY, S., and ROY, A. 2004. Molecular Markers in Phylogenetic Studies- A review. Journal of Phylogenetics and Evolutionary Biology. 2: 2-9.

SAHA, S., FERDOUS, Z., JAHAN, H., KHANDAKAR, A. M., SHAHJAHAN, R. M. and BEGUM, R. A. Polymorphic loci analysis of $16 \mathrm{~S}$ ribosomal RNA gene of Bombay duck (Harpadon nehereus). 2019. Bangladesh J. Zool. 47(1): 49-57.

WEISBURG, W. G., BARNS, S. M., PELlETIER, D. A. and LANE, D. J. 1991. 16S ribosomal DNA amplification for phylogenetic study. Journal of Bacteriology. 173: 697-703.

VENCES, M., THOMAS, M. VANDER, M. A., CHIARI, Y. and VIEITES, D. R. 2005. Comparative performance of the 16S rRNA gene in DNA barcoding of amphibians. Frontiers in Zool. 2:5-7.

WELSH, H. H. and OLLIVIER, L. M. 1998. Stream amphibians as indicators of ecosystem stress: a case study from California's redwoods. Eco. app. 8: 1118-1132.

YANG, L. and TRAN, V. 2014. Layer controlled band gap and anisotropic excitons in few-layer black phosphorus. Physical Review B. 89(23): 235-319.

(Manuscript received on 10 November, 2020 revised on 28 April, 2021) 